\title{
INTEGRATED URBAN DEVELOPMENT STRATEGY AS AN INSTRUMENT FOR SUPPORTING URBAN GOVERNANCE
}

\author{
A B S T R A C T
}

The paper will focus on the challenges of institutionalizing the new planning instrument - Integrated Urban Development Strategy (IUDS). ${ }^{1}$ It starts with a discussion on fostering innovations in urban governance, the impact of European urban development policies and the implementation of new planning instrument. Driven by demand for more effective and flexible planning, urban governance influenced the use of different instruments in practice. One of them is IUDS. The strategy development processes in three Serbian cities are the first examples of operationalization of the collaborative approach and IUDS in Serbia as the post socialist context which is adapting and adjusting to market oriented model. As such it holds endogenous character and meaning within the local planning practice. The key challenges of the strategy implementation are identified as understanding of the expected outcomes of its application and the existence of potential for change. With regards to the indicators of institutionalization of this new instrument, local planners have pointed out at the importance of providing further technical support, steps towards the implementation of the strategy, further capacity development, introduction of better communication as well as the establishment of relations. As a new instrument for urban development planning and supporting urban governance, the strategy has become the subject of analysis in the field of administration, professional and the academic community. 


\section{INTRODUCTION}

Several initiatives have been taken in the field of policies of integrated urban development, quality of life and better governance and in order to strengthen the economic position of cities in the European Union (EU). Frequent discussions on transforming institutions and procedures at all levels of government were encouraged by different objectives - from promoting competitive local economy to reducing the gap between citizens, businesses and the state. Debates in this field are often contradictory. They resulted with various forms of transformative initiatives at the local level. Urban governance is seen as a complex set of political entities, where participation, partnership establishment, coalitions, pacts, public dialogue and networks are conceived, in order to develop new policies and rules. Here, planning and urban governance are strongly associated and manifested through the development of strategic plans.

Through the discussions on urban governance, the need for flexible, innovative and responsible management is highlighted, including the shifting dynamics of global economic relations, recognizing the mobilization and active participation of society. Although the European model of urban development is based on economic, social and territorial cohesion and sustainability, the leading powers of these processes are neither individual nor unique in their direction ${ }^{2}$. They affect the community within a complex set of variable dynamics of economic relations, social needs and cultural preferences, but also in different expectations of what constitutes appropriate and legitimate forms of collective action. In a changing social environment, governance capacities assume a new role in relation to the allocation of material resources due to economic globalization and trends towards decentralization of functions and power leading to fragmentation of political, economic and social structures of the cities and the lack of public funds causes them to seek partners to achieve the set goals.

Development of strategic plans (for urban development) - integrated urban development strategies, was for the first time implemented in Serbia. As such, these strategies represent a test-ground for the collaborative approach in the local planning practice.

The past two decades evoked interest in the debate on collaborative planning as a form of action in practice. ${ }^{3}$ One of the key focuses of collaborative planning is strategic planning that has the priority task to take a role in establishing courses of action through a complex social dynamics. ${ }^{4}$ Serbian urban context represents fruitful base for investigating the possibility of operationalizing the collaborative approach to planning due to being characterized by rather complex social dynamics expressed through transition from socialist to market oriented model, decentralization, deregulation, problems of populations under 
increased risk of social exclusion and poverty, loss of urban identity, urban sprawl and occupation of agricultural and forest land, informal construction and usurpation of state owned land, etc.

Collaboration in the planning is based on the view that social groups and individuals are able to learn from each other, and that this knowledge affects behavior in decision-making. ${ }^{5}$ Here, the planning / governance is perceived as an active process in which social meanings are formed through discourse, and where social action provides legitimacy for the decisions being made.

Under the conditions of fast changes, conflicts and complexity, urban governance requires flexible systems that have capacities for urgent problem solving in order to face the contemporary challenges. Here, the collaborative action encourages a complex system to foster knowledge and progress. As such, it is based on a view that social groups are able to learn from one another. Moreover, it holds the ability to encourage joint action, creativity, adaptation and innovation. ${ }^{6}$

Collaborative planning model is a novelty in existing planning practice in Serbia which is commonly and traditionally related to rational planning approach. ${ }^{7}$ Current transition to market oriented planning and EU integration process imply harmonization with EU policies and influences the local planning practice. Thus, this paper aims to enhance some of the first experiences in operationalizing the collaborative model within the informal planning practice of three Serbian cities.

\section{EU INFLUENCIES}

When we say European city, what do we think of? European city consists of its geographical context, as well as spatial, social, political and value system and model $^{8}$. Although it was thought that the EU has no direct jurisdiction over the policies of urban and territorial development, the Lisbon Treaty (2007) contains provisions that provide legal basis for supporting the implementation of urban policies at different levels - invitation to economic, social and territorial cohesion, jurisdiction of local governments and the dimension of principles of subsidiarity (EU, 2014). Economic, social and territorial cohesion represent basic policies of the EU. As such, they carry a strong urban dimension. EU conducts the impact on urban development in two ways - primarily through structural policies where the financial incentives the Member States and their regions are obliged to comply with European policies; and secondary, through regulatory policies which create a binding legal framework for all Member States, especially through the guidelines of environmental or competition policy. 
Why is it important to point out the European policies of urban development? One reason is the process of European integration and opening of opportunities for Serbian cities to apply for European funds, but it is not essential. Moreover, some of the EU urban issues are similar to some of the issues of Serbian cities and towns. European urban development policies promote sustainable development, which is of special importance for Serbia where the political priority is given to the economic development and investment attraction. These are important, although insufficient, if we take into account the importance of quality of the environment and overall quality of life of citizens. At the same time, European policies promote understanding that introducing new planning instruments opens the thematic field of urban development planning, integrated and strategic approach, and linking the planning practice with realistic funding sources.

Similar to other European countries, Serbia represents a field for investigation of various planning and governance instruments, including the integrated urban development strategy. Implemented processes in Kragujevac, Užice and Kraljevo in the period 2011-14 represent the first experiences of applying the integrated and participatory approach in the planning of urban development in Serbia. ${ }^{9}$ Also important, these are the first experiences in implementing collaborative urban development planning in Serbia.

\section{ENCOURAGING NOVELTIES IN URBAN GOVERNANCE}

The topic of governance becomes one of the key "slogans" of the last decade. It covers different contexts, most of which are related to the difficulties in managing urban development. Urban governance refers to effective collaborative planning, processes (and mechanisms) of decision-making and their implementation in order to coordinate individual efforts of local governments, civil society organizations and commercial sector, according to the progressive realization of sustainable urban development and local democracy. As such, it essentially involves a new approach to the decision making process and expected outcomes, organization and institutional support and integrated development, which involves linking of sustainability, economic development, political views, social justice and cultural freedom.

Newer understanding of the concept of governance relies on the issue of distribution of responsibility, directing the urban governance in line with political arrangements and processes, decision making, responsibilities, relations between public corporations / agencies and allocation of resources. The concept of governance recognizes that power exists inside and outside the formal authority and institutions of government. Large number of definitions of governance includes three groups of actors: government, commercial sector and 
civil society. Also, the governance emphasizes the process by which decisions are made on the basis of complex relations between a number of stakeholders who have different priorities. Harmonization of conflicting priorities represents the essence of the concept of governance. Here are some of the accepted definitions:

- Urban governance is viewed as a collection of a number of different ways in which individuals and institutions, public and private sector plan and manage the common affairs of the city; it is a continuing process through which conflicting or diverse interests may be customized and take over activities through cooperation;

- "Good" urban governance is directly linked to the concept of wellbeing, and includes ensuring the availability of services such as adequate housing, security of property, drinking water, sanitary living conditions, clean environment, health, education and nutrition, employment, public safety and mobility. ${ }^{10}$

"Good" urban governance is expressed through standards. They are operationalized and embedded into principles that lead practice. They are characterized by: sustainability in all dimensions of urban development, subsidiarity, equity, efficiency (in the provision of public services and fostering of local economic development), transparency and accountability, involvement of citizens and urban safety. The tasks of urban governance involve the provision of: infrastructure for the efficient functioning of the cities; services that affect the development of human resources, improve productivity and raise the standard of living of the population; services and resources that support production activities and provide greater efficiency of the commercial sector, regulating of the activities of the commercial sector that affect the general welfare of the community and urban safety.

Urban governance involves establishing strategic directions and measures for implementation. These are identified as following:

1. Leadership and decision-making,

2. Coordination of different actors and activities - establishing trust, directing power, building consensus and managing conflict, as well as

3. Processes that support the introduction of change and adaptation, such are learning, evaluation and monitoring.

If comparing the experiences of applying the urban governance, the European practice emphasizes the context of local control which consists of various forms of collaboration and forms of governance. There, participation, partnerships, coalitions, pacts, public dialogue, networks and development activities represent a prerequisite for effective formulation and implementation of strategic plans. 
At the end of the twentieth century, the key challenges that have a direct impact on the planning of cities are recognized as globalization, sustainable development, European integration, economic reforms, market and demographic changes stood out. ${ }^{11}$ A decade later, what is highlighted are the global and European processes involving the decline of traditional manufacturing industries and the inexorable rise of the service sector, redefining of spatial relations and politicaleconomic framework, as well as significant changes from government to governance. ${ }^{12}$ Also, this period is recognized through the challenges of adapting to economic growth, dealing with the effects of climate change, management of demographic changes and ensuring social and territorial cohesion. ${ }^{13}$ Urban areas are the focus of the EU objectives of "smart, sustainable and inclusive growth", but also represent challenges of urban development "smart growth", sustainability and "urban sprawl". ${ }^{14}$ Modern problems of migration in Europe in 2015 will certainly initiate corrections of European urban policy. Recent initiatives are related to the integration of efforts to formulate an urban agenda, which is expected during 2016. Along with the traditional thematic field of urbanization trends, the relation of urbanization and environment, adequate housing and sustainable settlements, the priorities are expected in the field of economic and, in particular, democratic development, urban governance, respect for human rights (ensuring 'right to the city"), equality, urban safety, reducing the risk of disasters and increasing resistance of cities to changes ("'urban resilience"). ${ }^{15}$

Urban development policies represent a response to these challenges. As such, they are getting adapted and changed, and have become an integral part of European policies related to the promotion of balanced economic development, social cohesion, environmental protection and improving the quality of life in urban areas. New planning and governance instruments require innovations in approach to planning. In the field of urban governance, planning requires the introduction of participatory approach which involves the acceptance of specific ways of thinking, organizing and developing special culture of communication. Planning relies on a process of cooperation and collaboration, which takes place through interactive exchange of information and knowledge among participants of the planning process. The collaboration represents the result of multiple dimensions of planning, mutual impacts of different targets of urban development (economic, social, political, aesthetic), enhanced routing to specific projects, but also expectations related to the more effective planning, that is achieving visible results. Collaboration is based on the notion that none of the actors has the ability to achieve what he/she wants on his own (and to do it without the voluntary action of others, including local authorities). It is important that participants observe the project / plan through a perspective different than own. Each of the actors carries specific information and 
knowledge based on which he/she expresses views that result from different value perspectives. Moreover, they have different interests and / or values that often overlap. It is these overlapping values that hold potential to form the basis for action through collaboration.

The ability of planning to make a difference and change lies in the ability to recognize upcoming events and how to maintain or modify an existing operation. This includes recognition of the relationships between disputes and practices, as well as the search for opportunities within the public arena. There, different stakeholders have access to shared, collective observation of environmental quality and governance processes that allow action

\section{INTEGRATED URBAN DEVELOPMENT STRATEGY}

In practice, the integrated urban development planning is implemented through an approach based on the spatial dimension, linking resources with collaboration of various stakeholders, and is realized through integrated urban development strategies. ${ }^{16}$

Spatial dimension provides basis for identification of problems and potentials of the area, as well as communication and cooperation between the actors involved. This way it is possible to overcome the interest-oriented and limited sectoral policies. In addition to the integrated approach, it is important to highlight the need for participation of all relevant stakeholders and organization of the process, which focuses on the complexity of the problems and potentials of the area. Additionally, themes that are recognized significant are: coordination and cooperation between different levels of government, facilitating the conduct of communication with citizens, creating networks of administration and entities from surrounding, as well as enhancing local economy, involvement of representatives of public institutions and other relevant stakeholders in the planning and implementation of projects and activities.

The aim of the integrated urban development strategy is to contribute to the social, economic, environmental and spatial aspects of development. As such, the strategy is seen as a response to modern requirements due to linking economic, social, control and political components of planning with spatial and physical ones. It also includes participation in all phases of planning, introduces collaboration and, links the plan with financial and time frames and actors / institutions as holders of the activities who will implement it. Such document represents suitable instrument for the promotion of efficient urban areas, authentic socio-spatial pattern of social and spatial integration. Integration represents the basic procedural theme, which means that all policies, projects 
and proposals should be observed in conjunction with each other. The synergy between the elements should be regulated with regards to the desirable overall impact that should be stronger as a whole than realized through individual elements being implemented in isolation.

The strategy of integrated urban development sets the priorities for sustainable urban development - it aims for collaborative decision-making and agreeing on priorities. It also contributes to maximizing the value of financing the priority measures/projects and developing links within and outside environments. The formulation of strategy is a development process that is to derive with a document which includes: new knowledge about the area and ideas on how to improve the area, a vision of what the area might become, strategic goals and development activities, areas of intervention / activities, stakeholders, policy / measures for implementation, the time frame of activities and potential sources of funding.

Within last two decades the numbers of European cities were involved in the development of integrated urban development strategies, and especially after the adoption of the Leipzig Charter on cities in 2007. The implementation of the strategic urban development planning as a testing field for collaborative planning is a novelty in urban planning in Serbia where the integrated urban development strategy represents a new planning instrument.

\section{EXAMPLES FROM PRACTICE IN SERBIA}

The first steps in the implementation of integrated urban development strategies were made in the period 2011-2014 in three cities in Serbia - Kragujevac, Užice and Kraljevo. ${ }^{17}$ The development of a integrated urban development strategy of inner cities was tested in a form of pilot projects. ${ }^{18}$

In mid-2011 the processes of developing strategies began in Kragujevac and Užice, and in 2013 in Kraljevo as well. Resolutions on the preparation of the strategies were adopted by local assemblies and then working teams were formed, consisting of representatives of local government, public enterprises (urban planning, local economic development, investment management, housing, technical infrastructure, land, culture, education, social and health protection, environmental protection, heritage protection, sport and recreation, etc.) and NGOs (environmental protection, social protection, etc.). The main tasks of strategies were based on the identification of potentials of the space / location, defining the complexity of the structure and purpose of the revitalization of the identity of the city. The first step took form of an analysis of existing conditions in the different fields of action. The analysis of strengths and weaknesses as well as the evaluation of results and definition of need for interventions was 
performed. In addition to defining sectoral strategic, development directions through urban structures, public spaces, economy, infrastructure, housing, social and health protection, culture, education, etc., the focus of strategies was set on the formulation and coordination of a catalog of measures - a set of activities with certain carriers, financing method and timeframe.

The preparation of strategy involved a process of professional engagement, communication and participation, as well as evaluation of solutions where various stakeholders were involved. This kind of practice created a significant basis for actively directing the complex process of inner city development, but also providing prerequisites for the implementation of European policies of integrated urban development. One of the key features of the strategy is the participatory implemented planning process, which was consistently implemented on the examples in Serbia (Scheme 1). Local planners recognized results as the following: better identification of problems, generating ideas and evaluation of the proposals, improvement in work with citizens, increase of legitimacy, establishing cooperation between organizations, activating commercial and non-profit sector, and a new perception of "alternative" way of planning. ${ }^{19}$

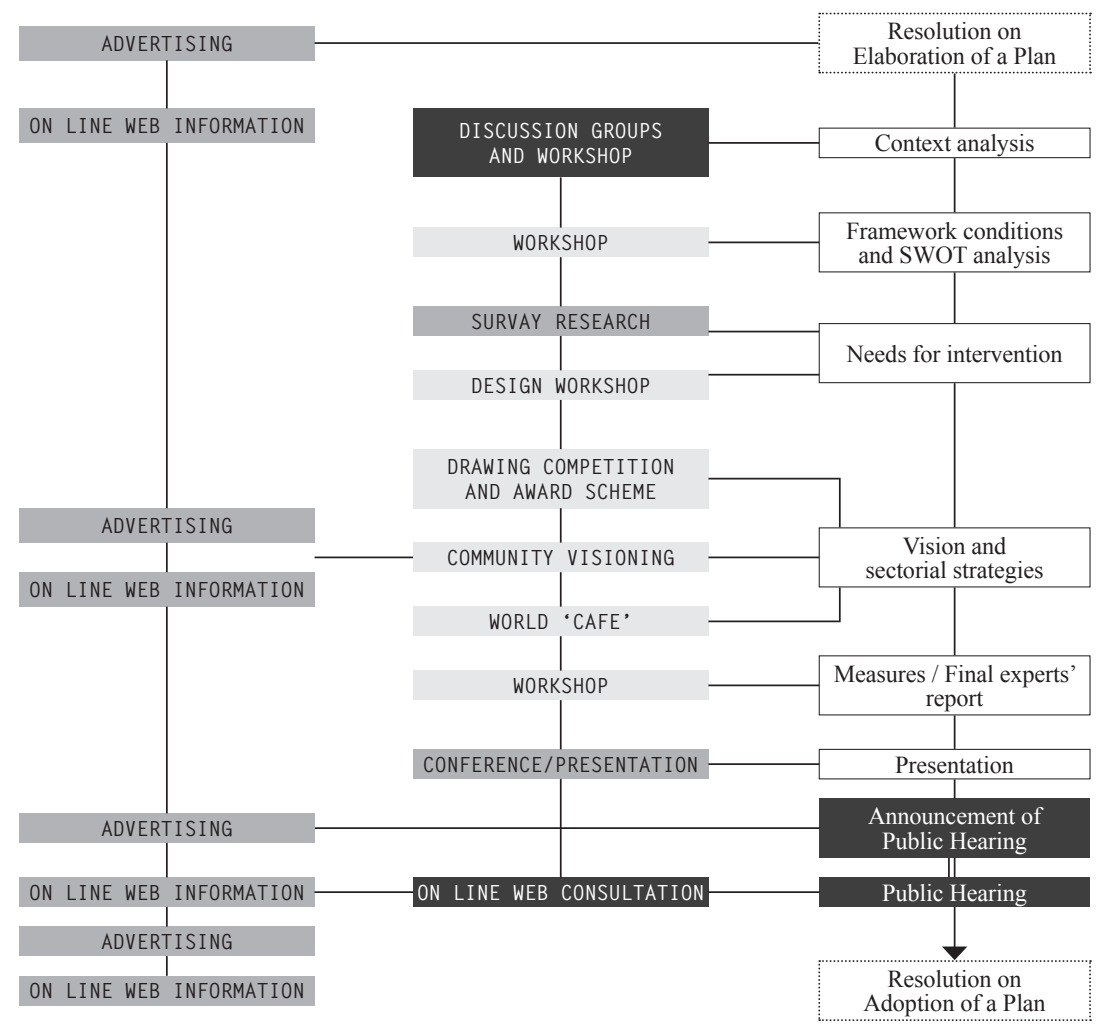


Different techniques of participation have been applied within the process:

1) informing - advertising, web advertising, questionnaire, conference;

2) consultations - discussion group, web consulting, public access;

3) active participation - workshop, design workshop, drawing contest, 'visioning', 'world cafe', public forum, and

4) feedback techniques - report, electronic information..$^{21}$

The experiences in participatory planning and drafting strategies of integrated urban development were presented at the meetings of professional associations and to the academic community in Serbia, as well as at international conferences (WUF VII in Medellin in 2014, Connective Cities in Leipzig in 2014 and LED in Tbilisi in 2015).

\section{CHALLENGES OF INSTITUTIONALISATION}

In the conditions of innovative practice, it is necessary to understand what the expected results and potential achievements of the strategy of integrated urban development are. Also, we need to understand the conditions for its implementation, as well as the possibilities for institutionalization and implementation capacities.

(1) Expected results and the range of strategy-The main field of strategy is planning and urban governance. Strategic planning should integrate different sectors, politics, resources, actors, knowledge, where strategy is the first step in the process of better urban governance. As such, it is expected to be effective in linking planning with different institutions and resources that may be acquired.

The contribution of integrated urban development is the provision of overcoming sectoral policies. In the field of urban development, strategy achieves the most significant effects in locating specific area interventions, which improve the urban environment and strengthen urban identity. The existing research on possibilities for its implementation suggest that these effects are manifested through following aspects: achieving greater national and international recognition; coordination of project initiatives; linking interventions of different parts of urban areas which are usually in different jurisdictions; linking development locations with key investments in infrastructure; fostering economic opportunities; limiting threats in maintaining the balance of the environment and, recognizing the cultural heritage that must be preserved. ${ }^{22}$ 
The strategy can contribute prosperity, social well-being and improvement of the environment, which requires the "political, economic and cultural consciousness and imagination, but also to be able to recognize human relations and place management, and understand the public interest and the quality of governance and the authorities". ${ }^{23}$ However, only some of the strategies are actually "strategic". In other words, only a few actually produced significant effects in addition to representing the formal way to attract funds for financing or were part of the legal framework. Some strategies have served political purpose as a "rhetorical decoration" of local politics, or as a confirmation to already established directions of development.

The analysis of possible effects of strategic planning stated that it is initiated in the conditions of expected changes. However, when it comes to the narrow field of strategic planning and urban development, it is significant to mention the analysis of the changes as one of the outcomes of planning. ${ }^{24}$ In relation to the potential for change, new research suggests the transformative potential of the strategy through the analysis of its interactive dimensions. These dimensions cover the reasons for the initiative, positioning interests, opportunities for increasing knowledge and selective ideas positioning into a common strategic framework. ${ }^{25}$

Should we, why and how enhance the strength and focus on solving urban problems? What is the real reason and the right moment to launch the initiative? Creating strategies in Kragujevac, Užice and Kraljevo was initiated by an international organization whose mission is to support the process of European integrations and better land management - minimizing the land consumption and urban sprawl.

The reason for initiative can also be the transformation of undeveloped and deprived areas, launching the development of key brownfield locations, better regulation of traffic, densification and intensification of the use of land and facilities in inner cities, creating a better urban identity and positioning of the city, increasing the attractiveness, necessity for harmonization of various initiatives of public and commercial sector, economic development and creating jobs, or all together. One of the national consultants involved in the strategy preparation explained: 'It took me time to understand the local context, development drivers and specific potential of each individual area in the city for Kraljevo it is its coastline along the river of Ibar and central urban matrix, while the city of Kragujevac is unique for the industrial cultural heritage." 
However, it should be noted that the most common reason for initiating the development of a strategy is possibility to apply for EU funds, as well as better coordination of sectoral policies. Local partners recognized these potentials: "the integrated approach encourages planning of the local budget, and provides a better insight into the financial needs of the different sectors, and can be used for accessing various national or EU financing sources and donor programs."

In whose interest is to develop a strategy? The strategy may be initiated by the local government (urban development department, local economic development agency, the cabinet of the Mayor), lobby groups, civil society and others. In the cities of Kragujevac and Kraljevo the initiators of strategies were local public enterprises for urban development, and in Užice that was the department for urban planning.

In addition to the importance of harmonizing sectoral policies, local planners have recognized the importance of collective effort:

" In development of this strategy the priorities and measures of sectoral strategies were taken into account, but the problem was only partially solved. The speed of change in these areas requires more frequent reassessment of existing solutions in order to respond to the issues long-term, and thus potentially eliminate negative impacts. Direct participation of relevant stakeholders in strategy development process contributes to its clearer profiling, and further promoted its position to be in the function of all stakeholders."

The essence in the process of strategy development is to combine efforts. Regardless of the carriers, the development of a strategy requires awareness of how collective action contributes dimensions and dynamics of urban development. This requires an approach that is focused on collective action.

The dynamics of urban development include introduction and development of various sources of knowledge about space to contribute recognition of the complexity and diversity of visions of future development. These contribute cognitive function of planning practice, too. Cognitive field means grouping and integration of different opinions, changing perceptions of what is the subject of common interest, agreement on the new issues and outcomes.

On the forum of citizens in Užice in an interview with local media, a local urban planner recognized the significance of the different views of development:

'I was particularly pleased with the fact that the introduction of today's gathering was the exhibition of drawings of the youngest citizens of Užice 
who presented their visions, aspirations and completely unencumbered views how Užice should look like in the future. Of course, life also brings the official models and frameworks that are limited by money. I hope that the young generations will have even more powerful visions of development of Užice than we do."”

Local town planner in Kragujevac pointed out at difficulties in the implementation and the importance of integration of different opinions:

"We learned a great lesson during the development of strategy. Politicians and experts had to come out of their offices, talk to citizens, but also to cooperate with other departments and institutions. Citizens had the opportunity to publicly assess and review the planning solutions. Strategy development and implementation of proposals were thorough and precise, and setting priorities was arranged according to the real needs and potential sources of funding."

In the case of Kraljevo participants recognized the significance of changes in perception of what the "common interest" can mean. One of the local planners recognized that "citizens' ideas should have crucial impact on the determination of priority projects". She explained:

"Most of the priority projects are associated with specific urban matrix of Kraljevo called "Little Chicago". We connected this project with complementary steps such are the development of the other bank of the Ibar river, reconstruction of bridges, formation of a communication axis. The aim is to increase the socio-economic integration of the two unevenly developed urban zones on two river banks. Direct contacts with the citizens in the form of interviews and subsequent public forum enabled them to express their ideas, opinions and desires. This includes improving the connectivity and mobility of the various parts of the city and renaturalisation of river banks as the lungs of the city."

Involving stakeholders and encouraging them to express their views publicly, through discussion and common assessment and selection enhances opening field of learning. Developing ideas through joint action opens the process of deliberation, active research, identifying, recognizing, remembering and learning about the problems and goals of the individual attitudes and on the occurrence of common attitudes and values. ${ }^{26}$ The cognitive function of planning is based on the ability to establish a public arena for discussion and joint action, which enables communication, interaction and socialization. ${ }^{27}$ 

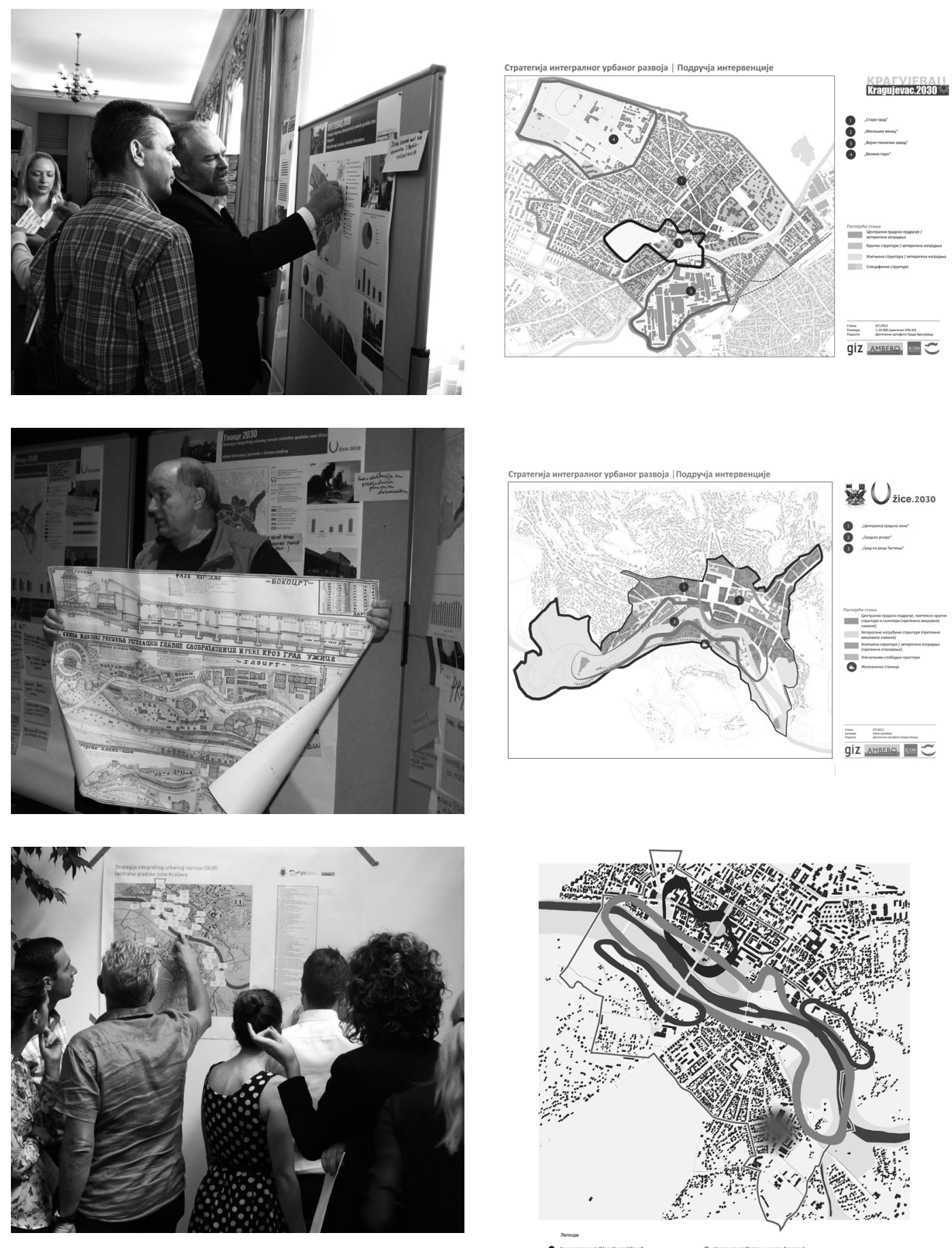

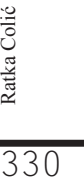

Figure 1 . The priority areas of intervention in IUDS in Kragujevac, Užice and Kraljevo 
Each strategy involves selective focus. It offers a way to identify topics, ideas, requests and arguments which are placed within concepts, images, or principles, As such, these new ideas and topics get meanings and provide guidance. Strategy provides the possibility for selection and it is oriented toward issues that really matter. ${ }^{28}$ The strategy is able to direct on "interventions as initiators of action" whereby, as recognized by local consultants: "the main task is how to sort out priorities because each of the actors has to be determined towards some of the priorities; and they should achieve agreement about it, especially from the aspect of funding possibility".

"Strategic" implies that some of the decisions and actions are seen as significant in relation to the others. Here, the planning process is related to decision-making on priorities, as well as to formulate fair and structural answers to the problems, challenges, aspirations and diversity. The strategy's potential is recognized in possibilities that it creates - to comprehend the problems and under-recognized potentials, to identify the places of "hidden power" where new coalitions for change can be created, to include new knowledge and to articulate strategic ideas. The very process of creating strategy involves checking the ability to make a selection and to provide simple solutions. ${ }^{29}$

(2) The introduction of novelties and institutionalization of changes - In the strategy implementation phase, indicators of institutionalization changes are the capacities of actors to effectively implement strategies, as well as their interrelations. This requires the existence of mechanisms for information exchange and dissemination, establishing partnerships, coordination of activities, coordination between institutions and work on joint projects..$^{30}$ As all three strategies are almost adopted, it is not to expect a detailed field for analysis but perceptions of local partners are of importance, expressed on the subject of further work on the strategies implementation. These expressions are focused on provision of institutional support, first steps towards the implementation, provision of further support to capacity building and introduction of better communication and establishment of relations.

The provision of institutional support includes the formation of professional teams (representatives of various sectors) and management structure that can monitor the implementation and communication of the strategy. Different modalities for establishment of units for implementation were stated in the process of strategies development. However, none of the three Serbian cities has achieved the formation of implementation units. Any proposal for the establishment of new management structures opens a dilemma - should there be a new institution or should we adapt existing governmental structures? As mentioned by local planners, "the formation of the implementation unit is especially important to 
ensure the institutionalization of knowledge and gained experiences. Especially in the circumstances when the staff is changing after elections."

Attempts to establish a joint work between the representatives of local institutions responsible for economic development, investment promotion and urban development planning are still at the initial stage. In Užice the first initiative was launched by Regional Development Agency, in Kragujevac by public company for planning, service for investment and Mayor's cabinet, while the cooperation between the Project Center in Kraljevo and public company for planning has not yet been realized in terms of further support to the implementation of the strategy. Here, it is evident that the activities on concrete projects are challenging due to difficulties in maintaining the continuity of cooperation between representatives of different sectors and institutions. This issue is reported by local planners: "unfortunately, the communication between different administrations is limited, everyone is responsible only for their field of activity, development of plans, economic development, without common platform on which to observe and unite the views."

It should be mentioned that all three cities faced political change in local authority after the elections. Therefore, it was to be ensured that there is a continuity of activities by establishing trust and political support for the process of strategies implementation. One planning professional explained:

"Soon after the strategy was made in Užice, the elections were held and the whole team that worked on the strategy has been replaced. We managed to persuade new political leaders to adopt a strategy, but it is difficult to maintain continuity and advance when you are constantly faced with political changes."

The phase of strategy implementation covers issues of implementation mechanisms, partners, and potential funding sources, work in stages and time frame, risk, coordination and monitoring.
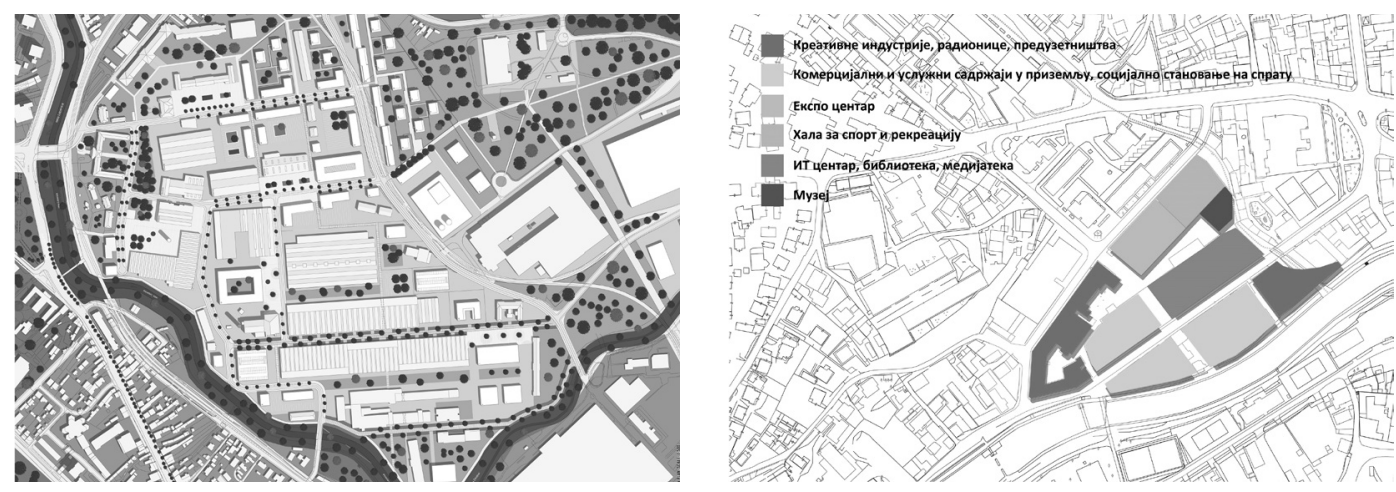
The first steps towards the implementation of strategies were made in Kragujevac and Užice in 2014 and 2015. These were the initiatives related to the development of brownfield locations. Kragujevac has decided to develop the site "Military Technical Institute" (supported by GIZ project). The City of Užice shows slightly different strategic priorities. At the initiative of the Women's Center 'Užice" and the Regional Development Agency 'Zlatibor", Užice has launched a project of social entrepreneurship within the site of the factory "Cveta Dabic", which is funded by the European Union under the cross-border cooperation program of Serbia-Montenegro.

Planning, implementation process and urban governance require additional knowledge and skills, or, capacity development. The process of preparing strategies in Kragujevac, Užice and Kraljevo obtained the technical assistance of German and Serbian experts. Participatory implemented processes of strategies development represented a testing ground for understanding and acquiring new knowledge and skills, but also allowed an insight into the lack of existing capacities. ${ }^{31}$

One of the key features of strategy is to link urban development planning with funding sources, which is a novelty for local planners. One local expert explained: "the introduction of funding sources is a language that politicians understand, and we thus can show the real potential of our proposals." The strategy preparation process was contributed by trainings and field-study trips. Additional capacities were essential in order to enhance local community in the field of urban governance: ' It is necessary to regularly obtain trainings and learn to think differently. We shouldn't only focus on the local budget, but also try to find alternative sources of funding."

The need for capacity development in the field of cooperation has been recognized. Local planners pointed out the importance of introducing better communication and establishing relations: "a significant innovation is close cooperation with public institutions and citizens, compared to the traditional distance between urban planners and other administrations (where urban planners usually conducted the planning process without the involvement of others), and where as a result unification of different views' is perceived."

The website about the process of strategy preparation in Kraljevo is the one of first examples of procedural transparency and informing the general public in Serbia ${ }^{32}$. In all three cities the process was followed by local media. The importance of transparency and strategy communication is recognized by local planners as well: 
"what needs to be improved is the dissemination of results; local selfgovernment is not used to the media promoting plans and strategies because it did not have to do that for decades... there is a lack of capacity and public awareness in the field of transparent planning procedures via digital media."

The capacity improvements on how to creatively respond and adapt to changes takes the central role. Capacity development still represents area for improvement. Therefore, further technical support is essential.

(3) An important issue relates to the implementation of the integrated urban development strategy in planning practice in Serbia. This subject should be considered at the different levels - administrative, professional, research and educational. These levels also represent a test ground for the applicability and sustainability of integrated strategic approach to planning and theory of collaborative planning as well.

The existence of European policies and programs that promote integrated urban development do not guarantee successful application in local practice. It is important to point out that since 2002 the competences and activities of local self-governments in Serbia have expanded. Hence, municipalities have legal ability to independently adopt their own development programs (in addition to urban plans that have been independently adopted for more than six decades, and spatial plans of the local government units in the last decade). Initiatives to supplement legal framework through development policies, under preparation of the draft law on the planning system in the Republic of Serbia, represent a part of the recent practice which prescribes the preparation of public policies. ${ }^{33}$ The integrated urban development strategy is a public policy document. In some European countries it is a part of the formal planning system (United Kingdom, Slovenia), and somewhere not (Germany). What is more important is the existence of a national program which provides a strategic framework and provision of financial support for implementation. The importance of the national program/ policy on urban renewal / regeneration of cities in Serbia has been recognized and implemented into the Planning and Construction Law in 2014.

Relevant, different approaches and methodologies for the preparation of local strategic plans for sustainable development require coordination and adjustment to the traditional local Serbian planning practice. According to the latest data mapping of strategic plans in June 2015, 897 planning process were registered at the local level (in 169 municipalities in Serbia, including urban municipalities) and 488 adopted strategic plans. ${ }^{34}$ Most of them are so-called comprehensive development strategies that include sustainable development strategies as 
well as various sectoral strategies in the fields of social protection, housing, including social housing, waste management, environmental protection, energy efficiency, agriculture, tourism, development of small and mediumsized enterprises and other. Development of these strategies is supported by international partners through donor development programs, but also through support of the state administration. ${ }^{35}$ As stated, the strategies were made in line with methodologies that required participation with relevant ministries. The integrated urban development strategy has its own specific methodology, directed by the spatial dimension. The experiences of international practices show possibility to develop methodological guidelines at national level. These act as a guide to facilitate implementation in practice, but also to define a framework and quality of development.

Another important aspect of integrated development strategies is the complexity of the urban problems. Serbian cities have similarities but also differentiate to other European cities. ${ }^{36}$ The differences in the ability to use resources and available funding are even more significant. ${ }^{37}$ However, it is important to point out the logic behind the integrated strategic planning. This is also addressed as "the problem approach" that initiated a dialogue and ultimately led to the designation of financial support from the EU, but also by the countries, regions and cities themselves. Originally deprived urban areas and neighborhoods had problems of socio-economic integration of the population, but, both geographical scope and subject matter of urban development has changed over time in accordance with the current problems and potentials of urban development. These were translated into policies.

The technical support for the development of strategies in Serbia was offered by German experts. When asked how they see thematic similarities and differences of "'local" and "German" strategies, German experts pointed out that there is no major difference except in the field of social and health care, education, culture and recreation. These are in the Serbian conditions far better represented, as a consequence of traditional organization of public sector and intensive participation of representatives of these institutions during the process of strategy formulation. What makes a crucial difference is the system of available sources of funding, especially in the implementation phase.

In urban development in Serbia the implementation of integrated approach and strategic urban development planning is a novelty. The IUDS is a new planning and governance instrument that integrates various aspects - economic development, social integration, better quality of life, improvement of environmental quality. Initiatives in Kragujevac, Užice and Kraljevo represent the first experiences and are a test ground for analysis and verification. In addition to traditional spatial 
/ physical planning, socio-economic planning and urban governance, defining institutional arrangements and establishing procedures for the implementation, integrated urban development strategies introduce new methods of work, new procedures, theories developed in a different setting, different practices, but also the demand for new knowledge.

At the academic level, the integrated urban development strategy of Kragujevac served as a training ground for work of students of master program Integrated Urbanism at the Faculty of Architecture 2014. ${ }^{38}$ From 2015 an elective course on this topic has been organized. It included problem-oriented approach and practice-oriented teaching.

\section{CONCLUSION}

It is evident that new challenges affect local communities. In these circumstances, local governments do not have functional instruments to direct the sustainable urban development. At the same time, new social actors are being created (local and those outside the municipality, even the state) and are having a growing impact. Cities and municipalities have to prepare for the new circumstances in which they have to cooperate with the commercial sector and civil society as partners. Contemporary conditions bring forward pressure to introduce alternative planning and governance models with a focus on issues of strategic development of cities. These efforts and activities are followed by the introduction of various planning / governance instruments including the integrated urban development strategies.

The introduction of innovations in the planning of urban development is achievable but it is important to understand and perceive some of the expected outcomes of such practice. In this paper we have focused on the enhancement of the application of the IUDS as a new planning instrument in accordance with EU urban policies. The preparation of integrated urban development strategy implies a participatory process that aims to define and implement urban development. It adapts to modern conditions, seeking planning approach that aims for direct, coherent, selective, and very important legitimate, intervention, reached through collaboration of different actors. The strategy is an instrument that connects planning and urban governance, ensures overcoming sectoral policies, locates priority spatial areas of intervention intended to improve the urban environment. Its potential for transformation effects the change. Transformative potentials are reflected in dimensions of the strategy initiation, interests positioning, opportunities for increasing knowledge and prioritization as setting selective ideas in common, as well as strategic framework. With regards to indicators of institutionalization of a new instrument, local planners have pointed out the importance of providing further technical support. Here, 
the first step towards the implementation of strategies required additional knowledge and skills as well as further capacity development, introduction of better communication and establishment of relations. The strategy, as new governance and planning instrument, has become a subject of analysis in the field of administration within professional and academic community.

The aim of capacity developing is to transfer the gained knowledge and skills from the alternative field of invention into the daily practice of a broader planning and urban governance environment. It is necessary to mobilize and create new ways of action and accept new knowledge. Institutionalization of changes means improvement of capacities and possibilities to create networks for collaboration between the actors, but it also relates to the introduction of new standards. Human resources and new knowledge are necessary in order to institutionalize changes.

Three pilot projects served as a testing field for implementation of the collaborative approach to planning. The importance of a collaborative approach has been recognized in the urban planning practice which is no more limited to directing and controlling of construction, but broadens range of influences on the development of capacities in a way that promotes long-term and sustainable improvement of quality of life.

One of the reasons for the implementation of collaborative approach is to distinguish new ways of decision making in public policies domain in order to establish an alternative to the traditionally imposed "top-down" solutions. Moreover, the procedures are more open and discursive to meet the requirements of individuals and general public. Tested cases have shown that the collaborative approach to planning in Serbian context contributed: better identification of problems, generating ideas and evaluation of the proposals, improvement in work with citizens, increase of legitimacy, establishing cooperation between organizations, activating commercial and non-profit sector, and a new perception of "alternative" way of planning.

Presented case studies are the first examples of operationalization of the collaborative approach and IUDS in Serbia as the post socialist context which is adapting and adjusting to market oriented model. As such it holds endogenous character and meaning within the local planning practice in applying the integrated strategic approach to planning. The introduction of innovation and institutionalization of changes takes time to understand and reflect on. The introduction of novelties also requires patience due to the time that is required for qualitative transformative changes. These are created through small steps and in various forms that eventually build a base for understanding and experience that are possible to unite through a transformative context. 
NOTES

N.B.
Svetlana Jevđović Matić (Assistant Mayor, Užice), Dragan Jevtović (Urban Planning Directorate Kragujevac), Marica Mijailović (Planning and Construction Directorate, Kraljevo), Ruža Penezić (Construction Directorate Užice), and Viktor Veljović (national consultant, Kraljevo) took part in interviews prepared, and participated in testing the integrated urban development strategies.

Author of the paper was engaged as a project manager for development of the Integrated Urban Development Strategies in Kragujevac, Uzice and Kraljevo, within engagement in GIZ/ AMBERO-ICON Project "Strengthening of Local land Management in Serbia" as national senior expert for urban planning.

The new public management was used as a theoretical inspiration of governance. It introduced new control instruments - strategic planning, performance indicators, monitoring, and involvement of the commercial sector and delegation of authority. Although criticized for technocratic approach and belief that the market mechanisms solve social problems as well, the new management approach is still popular. Some of the aspects of this approach are incorporated into the main directions of developing European policies, although there are also elements that are disabled. H., Wollmann and G. Marcou, "From public sector-based to privatized service provision. Is the pendulum swinging back again? Comparative summary," Edited by H. Wollmann/ G. Marcou (Elgar: Cheltenham, 2010), 240-260.

Healey, P. Collaborative Planning, Shaping Places in Fragmented Society. London: Macmillan Press. 1997a: xii.

P. Healey, Collaborative planning in perspective. Planning Theory 2/2 (2003): 101:24.

P. Healey, Collaborative planning in perspective. Planning Theory 2 (2) (2003): 101:24; J. Forester, The Deliberative Practitioner - Encouraging Participatory Planning Process. London: The MIT Press: 2000; E.J. Innes \& D.E. Booher "'Collaborative Dialogue as a Policy Making Strategy", Deliberative Policy Analysis: Understanding Governance in the Network Society (Eds. M.Hajer \& H.Wagenaar). London: Cambridge University Press: 2003.

E.J. Innes \& D.E. Booher 'CCollaborative Dialogue as a Policy Making Strategy”, Deliberative Policy Analysis: Understanding Governance in the Network Society (Eds. M.Hajer \& H.Wagenaar). London: Cambridge University Press: 2003.

N. Lazarevic-Bajec, 'Rational or collaborative model of urban planning in Serbia: Institutional limitations", Serbian Architectural Journal, (2011): 81-106.

W. Siebel lists five major characteristics of European city, that is: (i) " historically shaped place where civil society could evolve; (ii) has a written history of political and economic emancipation; (iii) the place of urban living, communications and experiences of diversity, separation of public and private sphere; (iv) historically developed shape and form, which is (iv) the result of planning and (v) is regulated by the welfare state, and shaped by the values, ethical norms and the principles of all city stakeholders", W., Siebel, Die europäische Stadt (edition suhrkamp) Taschenbuch. 2004. R. Colić, Understanding Urban governance - "Key stakeholders and their constructive partnership toward successful urban governance" (keynote), "Integrated and Citizen-Oriented Urban Development" Innovative instruments of Integrated Urban Development, LED Cities of Tomorrow. Organizer: City of Tbilisi, German Cooperation, Deutsche Gesellschaft fur Internationale Zusammenarbeit (GIZ)GmbH, Germany, May 5 ${ }^{\text {th }}$, Tbilisi, Georgia. 2015; H. Mueller and R. Čolić, "Sustainable and integrated urban development in Serbia." World Urban Forum WUF 7 UN-HABITAT, German Cooperation: Towards Sustainable Cities, Organizer: Engagement Global/ Service Agency Communities in One World, Deutsche Gesellschaft fur Internationale Zusammenarbeit (GIZ)GmbH, Germany, April $8^{\text {th }}$, Medellin, Columbia, 2014; R., Čolić,_"Strengthening of Local Land Management in Serbia." Connective Cities Launch Event "Sustainable Urban Development: Between Resource Efficiency and Sufficiency", Organizer: Federal Ministry for Economic Cooperation and Development BMZ, Deutscher Stadtetag, Engagement Global/ Service Agency Communities in One World, Deutsche Gesellschaft fur

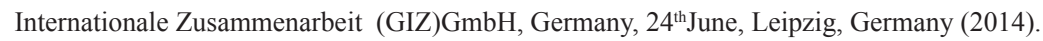


UN-HABITAT, Global Campaign on Urban Governance. Nairobi. http://www.unhabitat.org/ governance, 2002.

UNECE, Spatial Planning, Key Instrument for Development and Effective Governance (ECE/ HBP/146). UNECE, New York and Geneva. 2008.

P. Swianiewicz, R. Atkinson and A.Baucz, Background Report on the urban dimension of the Cohesion Policy post 2013.Report prepared at the request of the Polish EU Presidency. Warsaw, 2011.

German Bundestag (GB), Federal Ministry of Transport, Building and Urban Development (2012), 5 Years after the Leipzig Charter - Integrated Urban Development as a Prerequisite for a Sustainable City. Integrated Urban Development in the EU Member States and its Candidate Countries, 2012.

European Commission, Issues paper for discussion in the forum "CITIES - Cities of Tomorrow: Investing in Europe", Brussels 17-18 February 2014.

UN-HABITAT, UN- HABITAT III, What is the New Urban Agenda? Available at:

http://citiscope.org/habitatIII/explainer/2015/06/what-new-urban-agenda\#sthash.sdhyw5y7.dpuf, accessed 30.10.2015.

In EU documents the term used is an "Integrated sustainable urban development plan", in Germany "'Integriertes Stadtentwicklungskonzept", in UK"'Spatial Strategy", an "Integrated urban development Strategy" in Turkey, etc.

GIZ/AMBERO-ICON Project "Strengthening Land Management in Serbia" Available at: http:// www.urbanlandmanagement.rs

D.Jevtović, R.Čolić, I. Zerche, eds. The Integrated Urban Development Strategy of the Inner city of Kragujevac. Kragujevac: Direkcija za urbanizam Kragujevac, 2013; D. Radojičić, R.Čolić, I. Zerche, eds. The Integrated Urban Development Strategy of the Inner city of Uzice. Grad Uzice, 2013; N. Nerić, R, Čolić, J. Gauly, M. Engel, J. Gerhardt, eds. The Integrated Urban Development Strategy of the Inner city of Kraljevo. Belgrade: Urban Planning Directorat”Kraljevo", 2015.

After finished planning procedures in 7 cities and municipalities (Kragujevac, Kraljevo, Užice, Despotovac, Kladovo, Majdanpek and Smederevo), planners were interviewed. They expressed their opinion on the way how they see the results of the application of new methods of participation in the pilot test projects. Practical experience gained proved to be an impetus and encouragement for their views. R.Čolić, R. \& H.Mueller, ' Experts' Comments on Introduction of Participatory Tools in Urban Planning in Serbia." Proceedings of the 1.st International Academic Conference: Places and Technologies 2014. Belgrade, Serbia, 3-4. April, 1075-1083. 2014.

R. Colić, "Inclusive urban governance: Cities for citizens - Experiences from the Global North and South" - Case studies from Serbia, World Urban Forum WUF 7 UN-HABITAT, German Cooperation: Towards Sustainable Cities, Organizer: Engagement Global/Service Agency Communities in One World, April $9^{\text {th }}$ 2014. Medellin, Columbia, 2014.

R. Čolić, Dj. Mojović, Petković, M., Čolić, N., Guide for Participation in Urban Development Planning. Belgrade: GIZ - Deutsche Gesellschaft für Internationale Zusammenarbeit GmbH/ AMBERO-ICON, 2013.

P. Healey, "In Search of the "Strategic" in Spatial Strategy Making," Planning Theory \& Practice 10/ 4 (2009): 439-457.

Ibid.

R. Člić, "Strategija integralnog urbanog razvoja kao nov instrument planiranja urbanog razvoja." in Novi instrumenti planiranja prostora u tržišnim uslovima, procena vrednosti nepokretnosti, Međunarodni naučno-stručni skup Letnja škola urbanizma (eds. V. Trifunović, D. Radosavljević, N. Tesla, D. Minić), 35 - 44. UUS and RGZ. 29.-31. May 2012. P. Healey, "In Search of the "Strategic" in Spatial Strategy Making". 
R.Čolić, Participacija u strateškom planiranju gradova $i$ razvoj saznanja - primer strateškog plana razvoja Niša. Doktorska disertacija. Beograd: Arhitektonski fakultet Univerziteta u Beogradu, 2009.

L. Albrechts, "Strategic (Spatial) Planning Reexamined," (2004) 751-752.

L. Albrechts, "Strategic (Spatial) Planning Reexamined,"; P.Healey,"'Transforming governance: challenges of institutional adaptation and a new politics of space." European Planning Studies 14 (2006a): 299-319.

R.Čolić, Participacija u strateškom planiranju gradova i razvoj saznanja - primer strateškog plana razvoja Niša. Doktorska disertacija. Beograd: Arhitektonski fakultet Univerziteta u Beogradu, 2009.

R. Člić, 'Evaluation of the capacity development of actors within participatory planning process." SPATIUM International Review 31 (2014): 45-50; R. Čolić \& H. Mueller, 'Experts' Comments on Introduction of Participatory Tools in Urban Planning in Serbia." Proceedings of the 1.st International Academic Conference: Places and Technologies 2014. Belgrade, Serbia, 3-4. April, 1075-1083. 2014.

Available at: http://www.direkcijakv.net/siur-centralne-gradske-zone-kraljeva/

The following are listed: the strategy, the concept of policy, action program and plan, as well as the development plan and national development investment plan (Republički sekretarijat za javne politike (RSJP), Nacrt Zakona o planskom sistemu u Republici Srbiji, Radna verzija od 21.08.2015.godine.).

SKGO, EXCHANGE 4, Analiza (procena uticaja) strateškog planiranja i programskog budžetiranja na nivou lokalnih samouprava. Belgrade: 2015.

MIR 2, PRO, MSP NE, SDC MSP, USAID MEGA Exchange 2 and 3, DFID, the Government of Norway, the Provincial Secretariat for Local Self-Government of AP Vojvodina.

As stated in the report on the implementation of the Leipzig Charter (German Bundestag (GB), Federal Ministry of Transport, Building and Urban Development, 5 Years after the Leipzig Charter - Integrated Urban Development as a Prerequisite for a Sustainable City. Integrated Urban Development in the EU Member States and its Candidate Countries, 2012.), 'since in the 1980s urban development in the countries of Central, Eastern and Southeastern Europe has been under the influence of the globalization and the changing socio-economic systems, privatization, restructuring of the public sector. Although unemployment and poverty are the consequences of economic transition, socio-economic segregation, and thus the socio-spatial fragmentation, proved to be far less pronounced than in Western Europe. It is believed that in these cities the key challenges are economic development, urban renewal and provision of housing.' Is it only that? Serbian cities are affected by demographic aging, the brain drain of highly educated population, high unemployment, dilapidated technical infrastructure problems, uncontrolled expansion of cities and occupation of agricultural and forest land, informal construction and illegal usurpation of state land, environmental pollution, high degree of danger of flooding etc,

Especially in the countries of Central and Eastern Europe applying for EU funding, awareness of the integrated urban development (Bulgaria, Estonia, Hungary, Romania, and Slovenia) has been greatly raised. Despite the economic crisis, budget constraints and overall financial cuts, integrated urban development and related programs in many EU Member States have gained importance. Overall, the challenge in Europe will be to find a number of related courses of action on the subject of urban development, particularly through partnerships of national and local level, political and administrative spheres of the economy and citizens (German Bundestag (GB), Federal Ministry of Transport, Building and Urban Development, 5 Years after the Leipzig Charter - Integrated Urban Development as a Prerequisite for a Sustainable City. Integrated Urban Development in the EU Member States and its Candidate Countries, 2012).

M. Maruna and R.Čolić, eds. Integrated Urban Projects for Kragujevac Inner City Development. Final Works' Exhibition Catalogue: Generation of Students 2012-2013 (Belgrade: University of Belgrade, Faculty of Architecture, 2014. 
Albrechts, L., "From strategic spatial plans to spatial strategies." Planning Theory and Practice, 10 (1) (2009): 133-149.

Albrechts, L.," Strategic (Spatial) Planning Reexamined." Environment and Planning B: Planning and Design 31 (2004): 743-758.

Čolić, R., Participacija u strateškom planiranju gradova $i$ razvoj saznanja - primer strateškog plana razvoja Niša. Doktorska disertacija. Beograd: Arhitektonski fakultet Univerziteta u Beogradu, 2009.

Čolić, R., "Iskorak planiranja ka upravljanju urbanim razvojem," Lokalna samouprava Propisi $i$ praksa, Pravni bilten Stalne konferencije gradova i opština Srbije (2009): 39-47.

Čolić, R., "Upravljanje urbanim razvojem i uloga participacije”, Naučno-stručni skup sa međunarodnim učešćem, zbornik radova Lokalna samouprava u planiranju i uređenju prostora $i$ naselja (ur. V.Šećerov, B.Lukić, Z.Radosavljević, M.Marić), str.455- 464. Asocijacija prostornih planera Srbije, Univerzitet u Beogradu Geografski fakultet, Ivanjica, maj 2010.

Čolić, R., "Strategija integralnog urbanog razvoja kao nov instrument planiranja urbanog razvoja." in Novi instrumenti planiranja prostora u tržišnim uslovima, procena vrednosti nepokretnosti, Međunarodni naučno-stručni skup Letnja škola urbanizma (eds. V. Trifunović, D. Radosavljević, N. Tesla, D. Minić), 35-44. UUS and RGZ. 29.-31.maj, 2012.

Čolić, R., "Inclusive urban governance: Cities for citizens - Experiences from the Global North and South"- Case studies from Serbia, World Urban Forum WUF 7 UN-HABITAT, German Cooperation: Towards Sustainable Cities, Organizer: Engagement Global/ Service Agency Communities in One World, April $9^{\text {th }}$ 2014. Medellin, Columbia, 2014.

Colić, R., "Evaluation of the capacity development of actors within participatory planning process." SPATIUM International Review 31 (2014): 45-50.

Čolić, R. "Strengthening of Local Land Management in Serbia." Connective Cities Launch Event "Sustainable Urban Development: Between Resource Efficiency and Sufficiency", Organizer: Federal Ministry for Economic Cooperation and Development BMZ, Deutscher Stadtetag, Engagement Global/ Service Agency Communities in One World, Deutsche Gesellschaft fur

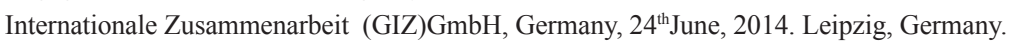

Čolić, R., Understanding Urban governance - "Key stakeholders and their constructive partnership toward successful urban governance" (keynote), "'Integrated and Citizen-Oriented Urban Development" Innovative instruments of Integrated Urban Development, LED Cities of Tomorrow. Organizer: City of Tbilisi, German Cooperation, Deutsche Gesellschaft fur Internationale Zusammenarbeit (GIZ)GmbH, Germany, May 5 ${ }^{\text {th }}$, Tbilisi, Georgia. 2015.

Čolić, R., Mojović, Dj., Petković, M., Čolić, N., Guide for Participation in Urban Development Planning. Belgrade: GIZ - Deutsche Gesellschaft für Internationale Zusammenarbeit GmbH/ AMBERO-ICON, 2013.

Čolić, R. \& Mueller, H., ''Experts' Comments on Introduction of Participatory Tools in Urban Planning in Serbia." Proceedings of the 1.st International Academic Conference: Places and Technologies 2014. Belgrade, Serbia, 3-4. April, 1075-1083. 2014.

Eurocities, The Changing Role of Cities in EU Cohesion Policies, May 28, Carnegie Europe, Brussels, 2013. available at: http://carnegieeurope.eu/2013/05/28/changing-role-of-cities-in-eucohesionpolicy/g2vf

European Commission, Issues paper for discussion in the forum "CITIES - Cities of Tomorrow: Investing in Europe", Brussels 17-18 February 2014.

Forester, J. The Deliberative Practitioner - Encouraging Participatory Planning Process. London: The MIT Press: 2000.

German Bundestag (GB), Federal Ministry of Transport, Building and Urban Development, 5 Years after the Leipzig Chater - Integrated Urban Development as a Prerequisite for a Sustainable City. Integrated Urban Development in the EU Member States and its Candidate Countries, 2012.

Griesel, Maart, and Frans van de Waart, eds., Multilevel Urban Governance or the Art of Working Together.Methods, Instruments and Practices. The Hague: 2011. 
Healey, P. Collaborative Planning, Shaping Places in Fragmented Society. London: Macmillan Press. 1997a.

Healey, P., Collaborative planning in perspective. Planning Theory 2/2 (2003): 101:24.

Healey, P.," Transforming governance: challenges of institutional adaptation and a new politics of space." European Planning Studies 14 (2006a): 299-319.

Healey, P., "In Search of the "Strategic" in Spatial Strategy Making." Planning Theory \& Practice 10/ 4 (2009): 439-457.

Innes, E.J. \& Booher D.E. ' 'Collaborative Dialogue as a Policy Making Strategy”, Deliberative Policy Analysis: Understanding Governance in the Network Society (Eds. M.Hajer \& H.Wagenaar). London: Cambridge University Press: 2003.

Jevtović, D., Čolić, R., Zerche, I., eds. The Integrated Urban Development Strategy of the Inner city of Kragujevac. Kragujevac: Direkcija za urbanizam Kragujevac, 2013.

Lazarević-Bajec, N., ' 'Rational or collaborative model of urban planning in Serbia: Institutional limitations", Serbian Architectural Journal, (2011): 81-106.

Maruna, M. and R.Čolić, eds. Integrated Urban Projects for Kragujevac Inner City Development. Final Works' Exhibition Catalogue: Generation of Students 2012-2013. Belgrade: University of Belgrade, Faculty of Architecture, 2014.

Mueller, H. and Čolić, R., "Sustainable and integrated urban development in Serbia." World Urban Forum WUF 7 UN-HABITAT, German Cooperation: Towards Sustainable Cities, Organizer: Engagement Global/ Service Agency Communities in One World, Deutsche Gesellschaft fur Internationale Zusammenarbeit (GIZ)GmbH, Germany, April $8^{\text {th }}$, Medellin, Columbia, 2014.

Nerić, N, Čolić, R., Gauly, J., Engel, M., Gerhardt, J., eds. The Integrated Urban Development Strategy of the Inner city of Kraljevo. Belgrade: Urban Planning Directorat"Kraljevo", 2015.

Radojičić, D., Čolić, R., Zerche, I., eds. The Integrated Urban Development Strategy of the Inner city of Užice. Grad Užice, 2013.

Republički sekretarijat za javne politike (RSJP), Nacrt Zakona o planskom sistemu u Republici Srbiji, Radna verzija od 21.08.2015.godine.

Siebel, W., Die Europäische Stadt (edition suhrkamp) Taschenbuch. 2004.

Swianiewicz, P., R. Atkinson and A.Baucz, Background Report on the urban dimension of the Cohesion Policy post 2013. Report prepared at the request of the Polish EU Presidency. Warsaw, 2011.

SKGO, EXCHANGE 4, Analiza (procena uticaja) strateškog planiranja i programskog budžetiranja na nivou lokalnih samouprava. Belgrade: 2015.

UNECE, Spatial Planning, Key Instrument for Development and Effective Governance (ECE/ HBP/146). UNECE, New York and Geneva. 2008.

UN-HABITAT, Global Campaign on Urban Governance. Nairobi. http://www.unhabitat.org/ governance, 2002.

UN-HABITAT, UN- HABITAT III, What is the New Urban Agenda?

http://citiscope.org/habitatIII/explainer/2015/06/what-new-urban-agenda\#sthash.sdhyw5y7.dpuf, 30.10.2015.

Wollmann, H. \& G. Marcou. "From public sector-based to privatized service provision. Is the pendulum swinging back again? Comparative summary." Edited by H. Wollmann/ G. Marcou, 240-260. Elgar: Cheltenham, 2010.

Working Paper of Urban Development. Trio Presidency of Spain-Belgium-Hungary (January 2010 - June 2011) [Internet].N.p. URL: http://www.rfsustainablecities.eu/IMG/pdf/TRIO PRESIDENCY EN cle0723b3.pdf 


\section{STRATEGIJA INTEGRALNOG URBANOG RAZVOJA KAO INSTRUMENT UPRAVLJANJA URBANIM RAZVOJEM \\ Ratka Čolić}

U radu je fokus na izazove institucionalizacije novog instrumenta planiranja - Strategije integralnog urbanog razvoja (SIUR). Započinje sa diskusijom o podsticanju novina u upravljanju urbanim razvojem, uticaju evropskih politika urbanog razvoja i primeni novog planskog instrumenta. Podsticano zahtevima za efektivnijim i fleksibilnijim planiranjem, upravljanje urbanim razvojem je uticalo na primenu različitih instrumenata u praksi. Jedan od njih je i strategija integralnog urbanog razvoja. Procesi izrade strategija u tri srpska grada predstavljaju prva iskustva operacionalizacije kolaborativnog pristupa i integralnog strateškog planiranja urbanog razvoja u Srbiji kao postsocijalističkom kontekstu, koji se prilagodjava tržišno orijentisanom modelu planiranja. Kao takav, poseduje endogeni karakter i značenje u okviru lokalne prakse planiranja. Kao ključni izazovi primene strategije izdvojeni su razumevanje očekivanih ishoda njene primene i postojanje potencijala za promene. U domenu pokazatelja institucionalizacije novog instrumenta lokalni urbanisti su ukazali na značaj obezbeđivanja dalje tehničke podrške, prve iskorake u implementaciji strategija, dalje razvijanje kapaciteta i uvođenje bolje komunikacije i uspostavljanje relacija. Kao novi upravljački i planski instrument strategija je postala predmet analize u sferi uprave, struke i akademske zajednice.

KLJUČNE REČI: UPRAVLJANJE URBANIM RAZVOJEM, STRATEGIJA INTEGRALNOG URBANOG RAZVOJA, PRVA ISKUSTVA U PRIMENI KOLABORATIVNOG PLANIRANJA URBANOG RAZVOJA, IZAZOVI IMPLEMENTACIJE

\section{PROSTORNI I SAOBRAĆAJNI RAZVOJ DUŽ EVROPSKIH KORIDORA: JAČANJE KAPACITETA LOKALNIH AKTERA \\ U TRANSNACIONALNOJ SARADNJI}

\section{Pablo Accebillo}

Integrisani prostorni i saobraćajni razvoj koridora je jedna od strategija kojom se utiče na trgovinu, ekonomski i demografski učinak u linearnim sistemima širom sveta. Međutim, takav razvoj se može razraditi na različitim nivoima: od istraživanja dinamike transnacionalne saradnje, preko analiziranja stepena integracije između prostornih i saobraćajnih politika u državama duž koridora, do fokusiranja na ulogu lokalnih aktera u nadnacionalnim pitanjima. Pošto ovaj rad predstavlja prvu fazu evropskog projekta transnacionalne saradnje u oblasti integrisanog prostornog i saobraćajnog razvoja duž Hamburg-Atina koridora u okviru programa infrastrukture iniciranog od strane Evropske Komisije, rad ima za cilj da pruži naučno zasnovan pregled najznačajnijih aspekata pomenutog koridora. Karakter rada je uglavnom opisni i shodno tome rasvetljava istraživanja u toku koja se sprovode kroz pomenuti projekat. U tu svrhu se koristi multi-skalarna perspektiva (tj. globalna, regionalna, lokalna) za analizu pojedinih indikatora vezanih za trgovinu, privredu i demografiju. Veruje se da takav temeljan prikaz obezbeđuje bolji pregled trenutne situacije. U završnom delu rada ukratko su date opšte preporuke za jačanje uloge lokalnih vlasti u složenom procesu transnacionalne saradnje.

KLJUČNE REČI: TRANSNACIONALNOST, TRGOVINA, EKONOMIJA, DEMOGRAFIJA, TRANSPORT, PROSTORNI

RAZVOJ, SARADNJA HAMBURG-ATINA KORIDOR

\section{RAZVOJ ŽELEZNICE I URBANI RAZVOJ U PATRASU: \\ KA UNAPREĐENJU UČEŠĆA LOKALNE SAMOUPRAVE U KOMPLEKSNIM PROBLEMIMA PLANIRANJA}

\section{Theodora Papamichail}

U poslednjih nekoliko godina, tema integrisane infrastrukture i urbanog razvoja, pored formalnih politika planiranja, promoviše pristup odozdo-na-gore. Ovo se posebno odnosi na kompleksne institucionalne okvire koje je potrebno osnažiti učešćem zainteresovane javnosti. Zbog društveno- 